Journal of Economic Theory 6(2): 61-65, 2012

ISSN: 1994-8212

(C) Medwell Journals, 2012

\title{
Islamic Banking Marketing
}

\author{
Abdel Wadoud Moustafa Moursi El-Seoudi, Mohd. Nasran Mohamad, Amir Husin Mohd. Nor, \\ Zaini Nasohah, Muhammad Nazir Alias and Nik Abdul Rahim Nik Abdul Ghani \\ Department of Syariah, Faculty of Islamic Studies, \\ Universiti Kebangsaan Malaysia, 43600 Bangi, Selangor, Malaysia
}

\begin{abstract}
The Islamic banking marketing is regarded as one of the crucial factors for developing and success of these banks in the far-scope time. The Islamic banks succeeded to offer modern banking services which have been professionally marketed. Although, the conventional banks have preceded it in that filed, it succeeded in expressing the Islamic banking. The concept of marketing is considered to be modern to the Islamic banking industry for it relied on the Muslims' Islamic sentiments in dealing with it. As to the present time, the competition enforced it to take much concern in that field.
\end{abstract}

Key words: Islamic banking, marketing, crucial factors, field, modern, Malaysia

\section{INTRODUCTION}

The Islamic banks that have succeeded in providing marketing services and Islamic banking in a modern and high quality and in many ways. This proves to us the success of Islamic banks in the marketing of its services, and the ability of Islamic banks to compete with conventional banks in this area. When talking about banking marketing, researchers have to differentiate between a comodity and a service. The commodity is a material thing which is not dealt with in the bank. However, bank offer services which the client cannot see or hear about unless he gets it. The aim is to meet the client's need and desire. So, marketing banking services which the bank does but it depends on good exhibition to the client. We can define marketing as all business activities which directs the flow of commodities and services from the producer to the final consumer or the industrial user.

The Islamic fiscal institutions consistently and constantly continued developing until a group of internal and external challenges emerged in the Islamic banking. A lot of questions, inquiries and suspicions were raised about the Islamic banking which received criticisms from different perspectives. A strong competition from the conventional fiscal institutions has occurred so it became incumbent on the Islamic banking authorities to establish marketing strategies through which these banks present the Islamic products and services they offer under a marketing plan based on a group of policies, principles and sharia settings and using a group of modern methods and mechanisms in the different technological fields.

\section{DEFINITION OF MARKETING}

The concept of marketing has passed many major and essential developments during the past century in parallel to the economical growths that the local and global economies experienced so that it develops and coins the modern concept of marketing.

Moreover, marketing is considered to be the vital, interesting, reality-based and daily-life field because it represents one of the contemporary challenges for business. Marketing is no more confined to merely selling and publicity and it becomes a complete activity characterized with complexity requiring scientific foundations and principles to make the efficient strategies and take decisions built on deep and analytical vision for available marketing chances and the environmental power influencing and available resources, particularly in the recent years where marketing has become basic and judgmental element in growing and success of business institutions under the strong rivalry requiring qualification and efficiency and builds marketing, competitive strategy and stand still before all challenges.

Perhaps, the first definition has enjoyed the acceptance for marketing by people of knowledge and commercial business, proposed by the American Marketing Association (AMA) in 1960 where it defined marketing as:

All business activities which directs the flow of commodities and services from the producer to the final consumer or the industrial user

Corresponding Author: Abdel Wadoud Moustafa Moursi El-Seoudi, Department of Syariah, Faculty of Islamic Studies, Universiti Kebangsaan Malaysia, 43600 Bangi, Selangor, Malaysia 
However, after a short time as a result of the big development in the field of the commercial businesses, this definition has met huge and wide criticisms because it limits the concept of marketing to be a job starting after producing the commodity and ending after merely selling it to the consumers. The marketing principles aim at dealing with the product before and after industrializing and producing it. That pushed the American Marketing Association to make other studies responding to the development and corresponding with the renaissance. Thus, the definition of 1985 which was as follows:

\section{Marketing is planning and executing operations of developing, pricing, promoting and distributing the commodities and services for creating alternative operations which realizes the goals of individuals and institutions}

As to Qahaf and Abdel-Salam (1996), he defines marketing as:

A social operation directing the economical flow of products and services from the producer to the consumer in a way which guarantees the correspondence between supply and demand and leads to realizing the society's aims

Kotler (1984) defines marketing as follows:

The social and economical mechanism by which needs and desires of the individuals and groups will be realized and satisfied through the way of producing and substituting the products and other things which has a value with the other

Kotler (1984) added an important dimension to marketing which is the social dimension that clarifies the aim of the marketing operation which is to meet the needs of the individuals and groups through creating and substituting products and values with the others. However, his definition has not included the basic dimensions that comprise the economical, legal and cultural aspects; its relation to the other functions that occurs in the business institutions such as purchasing and producing and the financial function and so on and no indication to the environmental conditions which have influence on the marketing operations in the production units. From those definitions of marketing and different inferences, researchers notice the following:

- Marketing is a modern science whose emergence in the beginning of the 19th century may have made it pass through many stages of evolution, leading to a big scope for innovation and renovation
- Some researchers adopted the holistic viewpoint in defining marketing whereas others partial viewpoint for marketing

The researcherss with the partial viewpoint look at marketing as a group of activities and technologies in the administrative framework that lead to satisfying the consumers' needs and realize the aims of the project through planning, pricing, promoting and distributing the product and that contribute in the needed satisfaction. For that reason, their analysis centers on the project and all that related to it.

The researchers with the partial viewpoint consider marketing as a social and economical operation aiming at realizing the society's goals through homogenizing between the heterogeneous supplies of commodities offered by the producers and the heterogeneous demand for commodities by the consumers. For that the analysis of the holistic viewpoint centers on the marketing functions performed on the society level to block the gap between supplies and demands (that is they view marketing as creating a better level of living).

\section{DEFINING THE BANKING MARKETING}

When talking about banking marketing, we have to differentiate between a comodity and a service. The commodity is a material thing which is not dealt with in the bank. However, bank offer services which the client cannot see or hear about unless he gets it. The aim is to meet the client's need and desire. So, marketing banking services which the bank does but it depends on good exhibition to the client. Marketing services are distinguished from marketing commodities in the following:

- It is a contact process to convince and attract clients with specific behaviors based on their different backgrounds

- It is designed and quiet process to fulfill the clients' desires with the easiest and simplest means

- This kind of marketing has intellectual and psychological influence to intellectually and psychologically prepare the client to respond to the institution or bank's service

- From this point, the view about the marketing activity has changed in the field of banking services, from merely announcing the bank's name and services to the necessity of studying the markets that banks serve, whether they are individuals or institutions, the concern about the clients' desires and aspirations when planning 


\section{J. Econ. Theroy, 6 (2): 61-65, 2012}

For this, banking marketing represents one of the pilars of the banking industry in the present time because it gives the conventional banks. From this point, there are numerous definitions for banking marketing. Murad (2007) defined it as:

The process through which bank services are directed to the client sufficiently and appropriately with realizing the maximum profit for the bank

Wayar, the British Ex-President of Barclays bank defined banking marketing as:

The administrative activity majored in delivering the banking services to the present clients and those targeted in the future

Ammary (2003) sees that banking marketing is a group of specialized and integrated activities through which bank resources and potentialities can be directed in moral frames targeting the realization of the highest levels of meeting the present and future needs and desires of the client and that always create successfully marketing chances for both the bank and the consumer of the banking service, equally. From those definitions, it becomes clear to us that:

- Banking marketing is an administrative activity for the bank or fiscal institution for delivering financially distinctive services to the maximum number of clients, in a way that guarantees the bank growth, profit, emergence and continuity

- It represents a contact process to persuade and attract clients with specific code of conduct

- It is an operation designed to achieve the clients' desires

- It depends on intellectual influence to mentally equip the client to respond to the service

Banking marketing gives much concern to discover new tools to gain new clients for the bank. It is not sufficient for the bank to have more financial resources, unless it finds various channels for investment. Also, the banking marketing in banks simultaneously produces and consumes in general. Thus, it is necessary for the client to attend and participate in the production because he is the main source of the recent and future sources of ideas in the banks and the financial banking institutions. All suggestions and opinions the clients provide lead to the formation of clear and appropriate ideas for future work, development of banking operation and facilitation of the staff tasks. Therefore, the client is regarded as the essential element of the banking marketing process and meeting his needs and desires is considered to be one of the most important factors banks look at considerably because he is the main reason for establishing banks (Aachoc, 2009). Thus, it becomes evident for us that pleasing the client is the aim the financial institutions and banks consider through the process of marketing their services.

\section{Aims of the banking marketing:}

- Achieving profits from the process of selling

- Beautifying the bank's reputation through

- Improving the level of banking services

- Enlarging the banking service base

- Enhancing the banking awareness for the bank personnel

- Developing financial and banking performance methods in the bank

- Encouraging the bank to innovate, create and grow through studying the market's demands and caring for the clients' desires and needs

- Having the bank remain and its operations continue through research, development and labour

- Training the staff in the bank to enhance their capabilities in dealing properly with the clients

- Preserving the bank's competitive level and growing its share in the banking market (Zaydan, 2003)

\section{BANKING MARKETING IN THE ISLAMIC BANKS}

In its initial stage of adopting the Islamic banking, the Islamic Banks depended on the Muslims' great Islamic sense and their support for everything in compliance with the Islamic Sharia in all aspects of life which has a great and efficient role in their success and soread. Muslims' strong feelings which support Islamic banking were the essential and first source in the Islamic investment and finance.

The Islamic fiscal institutions consistently and constantly continued developing, until a group of internal and external challenges emerged in the Islamic banking. A lot of questions, inquiries and suspicions were raised about the Islamic banking which received criticisms from different perspectives. A strong competition from the conventional fiscal institutions has occurred so it became incumbent on the Islamic banking authorities to establish marketing strategies through which these banks present the Islamic products and services they offer under a marketing plan based on a group of policies, principles and sharia settings and using a group of modern methods and mechanisms in the different technological fields (Aachoc, 2009).

As long as the Islamic bank offers services, it must make sure that these services are known by the clients, 
particularly when we know that people's needs require innovation and diversification from time to time. The Islamic bank must respond to this innovation and diversification unless it contradicts the teachings of the Islamic Sharia.

It is necessary for the Islamic banks to promote the Islamic thoughts relating to its field and the commodities they produce. It is obligatory for the Islamic banks to adopt a comprehensive marketing methodology so that it can be the alternative for the conventional banks in the modern banking practices in compliance with the Islamic Sharia.

\section{MARKETING IN THE ISLAMIC BANKS}

Islamic banks have conducted marketing process for its works and services since it was founded. That was based on the client's perspective, corresponding to its activity and deal facility to fully accomplish a distinguished service.

The eligibility of marketing in the Islamic Sharia is stemmed from the Prophet's statement: May Allah have mercy on a person who is tolerant to sell, to buy and to borrow. Tolerance here means treatment in its comprehensive meaning which the bank must care for when dealing with clients and their needs and aspirations and ensuring contacting and continually working with them. In addition, marketing represents the relation with the society, so it is the way to introduce the service benefits to the clients and persuade them to have them. Success of the service, distributing it and pricing it cannot appear except if the clients use it.

The annual plan of the Islamic banks indicated the policy of the bank in the process of marketing its services by forming a network of branches and banking marketing then it entrusted these branches to a lot of marketing operations, among which are improving the banking services under the existent rivalry whereby the Islamic Bank's strategy does not only care about what it offers to the client and achieving them but also going to the client and supply the services, particularly those newly found in the banking arena by adopting the best marketing ways of fulfilling the client's desires and meeting his needs which do not contradict the teachings of the Islamic Sharia.

In addition to the known services in the Islamic banks and the other banks such as ATM, money transfer, money exchange and deposit cards such as ATM, local and international VISA cards. The bank has introduced many modern electronic services like the service of businessmen and investors named private banking where the client is provided with a place to do his dealings. Also, there is the home banking by which the client can directly do any banking operation such as withdrawing and transferring money from his home. The Islamic Banks focused on developing marketing methods as follows:

Advertisement: Advertisement includes the activity types that lead to spread advertising visual messages through the TV and internet, auditory through radio, for the purpose of introducing new services and making the cliens on continual contact with the service advertised. Collecting the ads the Islamic bank did agrees with the Islamic sharia and the services of the Islamic bank are offered in a simple style which is. The Islamic banks has done many ads, among which are:

Visual ads: This is like the ad of the partnership extends from a generation to a generation in which the Islamic bsank presents its services having been offered to all of its clients since it was founded and how the bank contemporizes the fiscal and technological development to offer more advanced services to the coming generations. Moreover, many ads have been directed to a specific group such as the ads of financing the craftsmen in which the bank presents a model of financing services offered to its clients.

The read ads: The Islamic banks offered a lot of read ads which had a great impact in introducing its services and accomplishments. Among those ads is this ad. For the 3rd year, the Islamic bank is the best Islamic bank in retail services in the world in 2011.

This is one of the achievements that the Islamic bank is proud of and that expresses its sound end and means, by offering the best banking services and meeting the clients' needs who consider the Islamic financial industry based on the Islamic law. In addition, the bank has presented the clients who won in the campaigns of publicity and marketing the bank did.

Publicity: It represents the activity the Islamic banks offers to its clients, for instilling positive beliefs towards the bank's services. Many people see that publicity is stronger than ads because it centers on the desires of the clients straightaway and its means are the conferences, symposiums, seminars and stories.

The Islamic bank has executed many symposiums and conferences which presented the banking industry to the clients. That gained the Islamic bank a big resonance through its participation in the conferences organized by the Islamic bank for development, Al-Barakah Group for exchange, The General Council for Banks, the Islamic Financial Institutions, the Council of the Islamic Financial Services and the Authority of the Audit and Accounting for the Islamic Financial Institutions. 
Promise: The Islamic bank offers incentives to attract deposits such as promise by an award. These awards differ and diversify. They are offered as a type of good repay. That is implemented in an Islamic frame without prior promise or condition. Otherwise, it will be usury (Riba).

Promise by a gift: The bank offers a gift to everyone deposited a prominent deposit, for example the bank may pay all the expenses of the Hajj or Omrah once only.

Personal sale: Personal sale is considered the most important type of marketing that it deals with clients verbally for the sake of convincing them towards the presented services and it is the most important means to establish direct relations with the clients. Also, through personal sale, complaints and opinions of the clients can be checked and investigated. For this, the bank has sent most of its staff to take specialized courses in the banking marketing locally and externally by the agreement with Albarakah Group for Exchange in Bahrain and Abu-Ghazalah Institution for Employment Development in Saudi Arabia.

\section{CONCLUSION}

Despite the novelty of the concept of Islamic banking marketing in Islamic banks but these banks have succeeded in providing excellent banking services and has worked to market effectively. The Islamic banks that have succeeded in providing marketing services and Islamic banking in a modern and high quality and in many ways. This proves to us the success of Islamic banks in the marketing of its services and the ability of Islamic banks to compete with conventional banks in this area.

\section{ACKNOWLEDGEMENT}

Part of this stady is an outcome of research was conducted by using the research funding of the UKM-PP05-FRGS0170-2010 Project.

\section{REFERENCES}

Aachoc, A., 2009. Marketing of banking services in Islamic banks. Master Thesis, Faculty of Economic Sciences, University Hadj Lakhdar, Batna.

Ammary, J., 2003. Marketing in the Algerian banking institution. Journal of the Researcher, The Number 2, Annual Reports of the Jordan Islamic Bank.

Kotler, P., 1984. Marketing management: Analysis, Planning and control. Prentice Hall, New Jersey, USA.

Murad, A.S., 2007. Activation Marketing to Counter the Effects of GATS. Arab Bureau, Egypt.

Qahaf, A. and Abdel-Salam, 1996. Marketing Basics. Department of Business Administration, Alexandria University, Egypt.

Zaydan, M., 2003. The role of marketing in the banking system to increase the competitiveness of banks. Research Publication, Journal of the Researcher, The Number 2. 